\title{
Effect of 5-aminolaevulenic acid on postoperative lactate levels in patients undergoing surgery for malignant brain tumours
}

\author{
G Baake $^{1 *}$, FE van Gelder ${ }^{1}$, W Bult ${ }^{1,2}$, MW Nijsten ${ }^{1}$ \\ From ESICM LIVES 2015 \\ Berlin, Germany. 3-7 October 2015
}

\begin{abstract}
Introduction
5-aminolaevulinic acid (5-ALA) is a natural precursor of haemoglobin. Exogenously administered 5-ALA can lead to intracellular accumulation of fluorescent porphyrins in malignant tissues, such as glioblastoma. 5-ALA is increasingly used to improve tumour visualisation and enable more optimal resection of malignant gliomas. In vitro, 5-ALA can cause oxidative damage to rat liver mitochondria. In vivo, rats exposed to 5-ALA developed increased lactate levels; possibly because inhibition of oxidative metabolism [1]. Univariate data also suggested an effect of 5-ALA in neurosurgical patients [2]. Since lactate levels are widely used to monitor patients, we performed multivariate analysis on the impact of 5-ALA on lactate levels.
\end{abstract}

\section{Objectives}

Asses the relation of preoperative 5-ALA on postoperative systemic lactate levels in patients undergoing surgery for malignant brain tumours.

\section{Methods}

In an observational study in a cohort of neurosurgical patients who underwent resection of a suspected malignant glioma and were postoperatively admitted to our ICU, we compared lactate levels between patients who received 5-ALA preoperatively (5-ALA group) and those who did not (control group). The decision to use 5-ALA was at the discretion of the neurosurgeon and was based on the specific tumour characteristics on preoperative imaging. If fluorescent-guided resection was scheduled, the patient received $20 \mathrm{mg} / \mathrm{kg}$ of 5-ALA (Gliolan, Medac,

'University Medical Center Groningen, Department of Critical Care, Groningen, Netherlands

Full list of author information is available at the end of the article
Germany) orally 2 hours before the induction of anaesthesia. All patients received high-dose dexamethasone. Periand postoperative lactate and glucose levels were routinely obtained during the ICU stay in all included patients in this study using a point-of-care analyzer blood gas analyser.

\section{Results}

From 2007 to 2014 we included 350 patients aged $56 \pm 14$, $60 \%$ males. 89 patiens (25\%) received 5-ALA. These patients were older than controls ( $62 \pm 8$ vs. $53 \pm 15$; p < 0.001 ); duration of operation did not differ between the control and 5-ALA groups (NS). On day 0 the mean maximum lactate in the 5-ALA vs control groups was $2.83 \pm$ 1.34 vs $2.47 \pm 1.24 \mathrm{mmol} / \mathrm{L}(\mathrm{p}=0.02)$. On the first postoperative day the lactate levels were similar. Multivariate analysis showed that age $(\mathrm{p}=0.02)$, duration of operation $(\mathrm{p}=0.04)$ and glucose $(\mathrm{p}<0.001)$, but not 5 -ALA $(\mathrm{p}=$ $0.43)$ were related with lactate.

\section{Conclusions}

5-ALA use was only univariately associated with increased postoperative lactate levels. MV-analysis, strongly points to a central role of hyperglycemia, as was recently also observed after cardiac surgery [3].

\section{Authors' details \\ ${ }^{1}$ University Medical Center Groningen, Department of Critical Care, \\ Groningen, Netherlands. ${ }^{2}$ University Medical Center Groningen, Hospital \\ Pharmacy, Groningen, Netherlands.}

Published: 1 October 2015

\section{References}

1. Pereira B: 5-Aminolevulinic acid induced alterations of oxidative metabolism in sedentary and exercise trained rats. J Appl Physiol 1992. (c) 2015 Baake et al.; This is an Open Access article distributed under the terms of the Creative Commons Attribution License (http:// creativecommons.org/licenses/by/4.0), which permits unrestricted use, distribution, and reproduction in any medium, provided the original work is properly cited. 
2. Abbasova I: Lactate levels in patients who preoperatively receive 5-ALA. ESICM 2009.

3. Ottens TH: Effect of high-dose dexamethasone on perioperative lactate levels and glucose control: a randomized controlled trial. Crit Care 2015

doi:10.1186/2197-425X-3-S1-A976

Cite this article as: Baake et al: Effect of 5-aminolaevulenic acid on postoperative lactate levels in patients undergoing surgery for malignant brain tumours. Intensive Care Medicine Experimental 2015 3(Suppl 1):A976.

\section{Submit your manuscript to a SpringerOpen ${ }^{\circ}$ journal and benefit from:}

- Convenient online submission

- Rigorous peer review

- Immediate publication on acceptance

- Open access: articles freely available online

- High visibility within the field

- Retaining the copyright to your article

Submit your next manuscript at $\gg$ springeropen.com 